\title{
Grand-Pressigny was not alone: Acquiring and sharing data about raw materials in the collective research project "Réseau de lithothèques en région Centre-Val de Loire" (France)
}

\author{
Vincent Delvigne $^{1,2}$, Paul Fernandes ${ }^{2,3}$, Christophe Tuffery ${ }^{4,5}$, \\ Raphä̈l Angevin ${ }^{6,7}$, Harold Lethrosne ${ }^{8}$, Thierry Aubry ${ }^{9}$,
} Marie-France Creusillet ${ }^{8,10}$, Jean Dépont ${ }^{11}$, François-Xavier Le Bourdonnec ${ }^{12}$, Audrey Lafarge ${ }^{13}$, René Liabeuf ${ }^{14}$, Xavier Mangado-Llach ${ }^{15}$, Marie-Hélène Moncel ${ }^{16}$, Michel Philippe ${ }^{5,17}$, Michel Piboule ${ }^{14}$, Jérôme Primault ${ }^{7,18}$, Jean-Paul Raynal ${ }^{2,19}$, Clément Recq ${ }^{20}$, Marta Sanchez de la Torre ${ }^{15,21}$, Gabriel Teurquety ${ }^{7}$, Christian Verjux ${ }^{7,22}$

1. Service de Préhistoire, Université de Liège, place du XX août, 4000 Liège, Belgium.

Email: vincent.delvigne@ hotmail.fr

2. UMR 5199 - PACEA, Université de Bordeaux, allée Geoffroy Saint Hilaire, 33615 Pessac, France.

3. SARL Paléotime, 6173 rue Jean Séraphin Achard Picard, 38350 Villard-de-Lans, France.

Email: paul.fernandes@paleotime.fr

4. INRAP, DST/ Sous-direction Pilotage de l'activité opérationnelle et méthodes, 121 rue d'Alésia - CS20007, 75685 Paris, France. Email: christophe.tuffery@inrap.fr

5. UMR 7324 CITERES-LAT, Université François-Rabelais/CNRS, BP 60449, 37204 Tours cedex 3, France.

6. DRAC Auvergne-Rhône-Alpes, SRA Auvergne,4 rue Pascal, 63000 Clermont-Ferrand, France. Email: raphael.angevin@culture.gouv.fr

7. UMR7041 - ArScAn, Maison de l'archéologie et de l'ethnologie, 21 allée de l’Université, 92923 Nanterre, France. Email: gabriel.teurquety@gmail.com

8. UMR8215 - Trajectoire, Maison de l'archéologie et de l'ethnologie, 21 allée de l'Université, 92923 Nanterre, France. Email: lethrosneharold@gmail.com

9. Fundação Côa Parque, Rua do Museu, 5150-620 Vila Nova de Foz Côa, Portugal. Email: thaubry@ sapo.pt

10. INRAP - Centre-Île de France, 525 avenue de la pomme de pin, 45590 Saint-Cyr-en-Val, France.

Email: marie-france.creusillet@inrap.fr

11. Muséum d' Histoire Naturelle de Bourges, 9 Allée René Ménard, 18000 Bourges, France.

Email: depont.jean@gmail.com

12. UMR 5060 - IRAMAT, IRAMAT - CRP2A, Université Bordeaux Montaigne, Esplanade des Antilles, 33607

Pessac, France. Email: francois-xavier.le-bourdonnec@u-bordeaux-montaigne.fr

13. UMR 5140 - Archéologie des sociétés méditerranéennes, Université de Montpellier 3, route de Mende, 34199 Montpellier, France. Email: audreylafarge0@gmail.com

14. Independent researcher. Email: Liabeuf: maufhisti@gmail.com; Piboule: piboulemichel@gmail.com

15. Seminari d'Estudis i Recerques Prehistòriques (SERP), Universitat de Barcelona, 6-8 Montalegre,08001 Barcelona, Spain. Email: mangado@ub.edu

16. UMR 7194 - Département Hommes et Enviornnement, Muséum National d'Histoire Naturelle, 1 rue René Panhard, 75013 Paris, France. Email: moncel@mnhn.fr

17. Musée de Préhistoire du Grand-Pressigny, 37350 Le Grand Pressigny, France. Email: mphilippe@departement-touraine.fr

18. DRAC Nouvelle Aquitaine, SRA de Poitou-Charentes, 102 grand'rue, 86020 Poitiers, France. Email: jerome.primault@culture.gouv.fr

Published by the School of History, Classics and Archaeology, University of Edinburgh ISSN: 2055-0472. URL: http://journals.ed.ac.uk/lithicstudies/

Except where otherwise noted, this work is licensed under a CC BY 4.0 licence. 
19. Department of Human Evolution Max Planck Institute for Evolutionary Anthropology, DeutscherPlatz 6, 04103 Leipzig, Germany. Email: jpraynal@wanadoo.fr

20. Association archéologie pour tous, 23 Allée de Chambord, 41220 Saint-Laurent-Nouan, France.

Email: clement.recq@gmail.com

21. Dpto. Ciencias de la Antigüedad (PPVE) - IUCA, Universidad de Zaragoza. 12 Pedro Cerbuna, 50009

Zaragoza, Spain. Email: sanchezdelatorre@unizar.es

22. DRAC Centre-Val de Loire, SRA Centre-Val de Loire, 6 rue de la Manufacture, 45000 Orléans, France.

Email: christian.verjux@culture.gouv.fr

\begin{abstract}
:
In the wake of the discovery of numerous large blade workshops at Le Grand-Pressigny site (Indre-et-Loire, France), which initially aroused great interest, the mid-Loire Valley region became central to studies of flint diffusion. Despite the quality of the initial work, the widely shared view now is that the capacity for this concept to continue to provide useful archaeological modelling has diminished. Establishing real and actual correlations between archaeological objects and geological samples remains difficult, making it almost impossible to determine the source of certain materials represented in an archaeological series. In response to this problem, the French collective research project "Réseau de lithothèque en région Centre-Val de Loire" assembled about 30 amateur and professional researchers from various European institutions to work on three strategic missions:

- Mission 1: establish a list of current lithotheques ("rock-libraries" or comparative collections), verify their contents and complete them if necessary;

- Mission 2: link the major types of depositional environments with the properties acquired by flint through its life;

- Mission 3: spread knowledge and information both within the project and to all interested persons.

The project is closely associated with similar French programs already in place in AuvergneRhône-Alpes and Aquitaine regions. The ultimate objective is to build a national and international community around a common project, bringing participants together regularly to share knowledge and technical expertise.
\end{abstract}

Keywords: lithotheque (rock-library); petroarchaeology; methodology; raw materials sourcing

\title{
1. Introduction
}

\subsection{Geographical, geological and historiographical background}

The mid-Loire Valley region, located in central France, has a surface area of about $39,000 \mathrm{~km}^{2}$. It is a vast agricultural region, with a relatively sparse population, divided into six departments: Eure-et-Loir, Loiret, Loir-et-Cher, Cher, Indre and Indre-et-Loire. In this paper we focus on the southernmost departments where we began our work. This region is a succession of hills and low plateaus extending northwards from the mountainous margin of the Massif Central. Four major rivers, which attracted prehistoric settlement, drain this area: the Loire, which crosses it from east to west and three of its left bank tributaries: the Cher to the east, the Indre at the center and the Creuse to the west (Figure 1). 


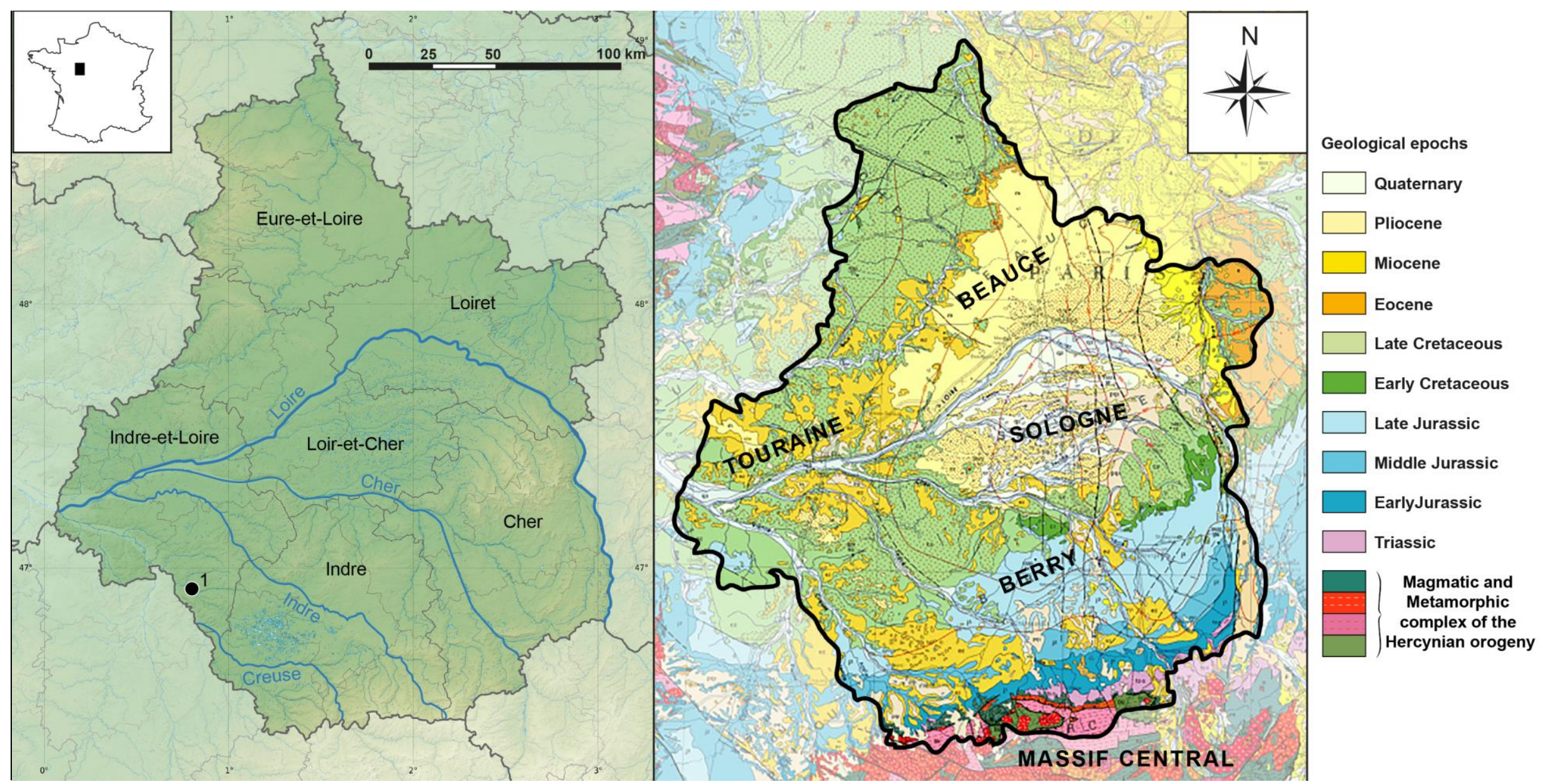

Figure 1. On the left: topographical map of the Centre-Val de Loire région; on the right: geological map of the Centre-Val de Loire region. Black dot (1) represent the GrandPressigny. 
Geologically, the mid Loire Valley belongs to the south-west of the Paris Basin where four main geological formations are recognized (Figure 1):

(1) Tertiary formations covering much of the central and north-eastern part of the region, consisting mainly of lacustrine limestone in Beauce and sand and clays in Sologne. Scattered residual lacustrine and palustrine limestones rest on the Jurassic formations further to the south-west;

(2) Cretaceous chalks and clays containing flint (the remains of chalk weathering), occur in the west and the central portion of the region bordering Sologne and Beauce;

(3) Jurassic limestones of the Berry outcrop in the south of the region where Middle and Early Jurassic units form the foothills of the Massif Central; and

(4) Crystalline basement rocks of the Massif Central outcrop on the southern edge.

Most of this landscape, except for the Sologne and the northern margin of the Massif Central, is host to numerous silicified rocks of chemical, biochemical or diagenetic origin (abbreviated SRO in the rest of the text) of various types including flint, chert, silcrete and jasperoid, all of which have been exploited by prehistoric humans. Although primary outcrops are rare, in-situ and reworked clays containing flints are widespread at the top of the Cretaceous chalk and these valuable resources were exploited extensively (Figure 2).

The first references to flint sourced from the southern Paris Basin archaeological series and dispersed over several hundred kilometers date back to the nineteenth century (Pomerol 1888) with special attention given to flints from Berry and Touraine. Mostly, the focus centered on the Grand-Pressigny Upper Turonian formation (e.g., Chabas 1874; Charbonnier 1962; Cordier 1956; Gardez 1933; Giot et al. 1986; Giraud 1955; Hue 1910; Masson 1981, 1986; Munck 1928; Saint-Venant 1891; 1910; Valensi 1957) and the widespread diffusion of Upper Turonian flints in the Neolithic (e.g., Delcourt-Vlaeminck 1998; Mallet 1992; 2001) and Palaeolithic periods (e.g., Aubry 1991; Aubry \& Walter 2003; Delvigne et al. 2017; Fontana 2005; Fontana et al. 2018; Kildéa 2008; Klaric et al. 2011 ; Primault 2003a; 2003b; Surmely 2000; Surmely \& Pasty 2003). Less well-known, Lower Turonian flints from Berry have also attracted archaeologist's attention (e.g., Aubry 1991; Grattier 1977a; 1977b; Masson 1981; Primault 2003a; Surmely et al. 1998; 2008; Valensi 1955a; 1955b) once they were recognized in Palaeolithic lithic series occurring several hundred kilometers away from their source (review in Delvigne et al. 2018).

While most research has focused on these two types of flint, many other formations containing SRO in the mid-Loire Valley region have supplied SRO material, that were sometimes extensively used prehistorically and have been recovered far from their sources (Delvigne 2016). However, much of the regional diversity of SRO - in both genetic and gitological terms (see 2 below) - remains unknown and only a few publications provide details on this subject (e.g., Aubry 1991; 2015; Debrand-Passard 1982; Delvigne 2016; Gratier \& Macaire 1978; Irribaria 1992; Lablanche 1982; Lethrosne \& Despriée 2014; Lorenz 1992; Mouhsine 1994; Person et al. 1994; Piboule et al. 2018; Primault 2003a; Surmely 2008; Thiry et al. 1983; Valensi 1953; 1954). There is a difference therefore in the quality and quantity of data available in the literature and in lithotheques in terms of geographical distribution and relevant geological formations.

The result is that despite the quality of the initial work, difficulties remain in making correlations between archaeological objects and geological samples and therefore an inability to determine the source of some archaeological materials occurring in lithic collections. Awareness that we must go beyond the previous work in order to continue to provide useful archaeological models, is widely shared by the archaeology community and was the basis on which the above named Collective Research Program (PCR) was established. 

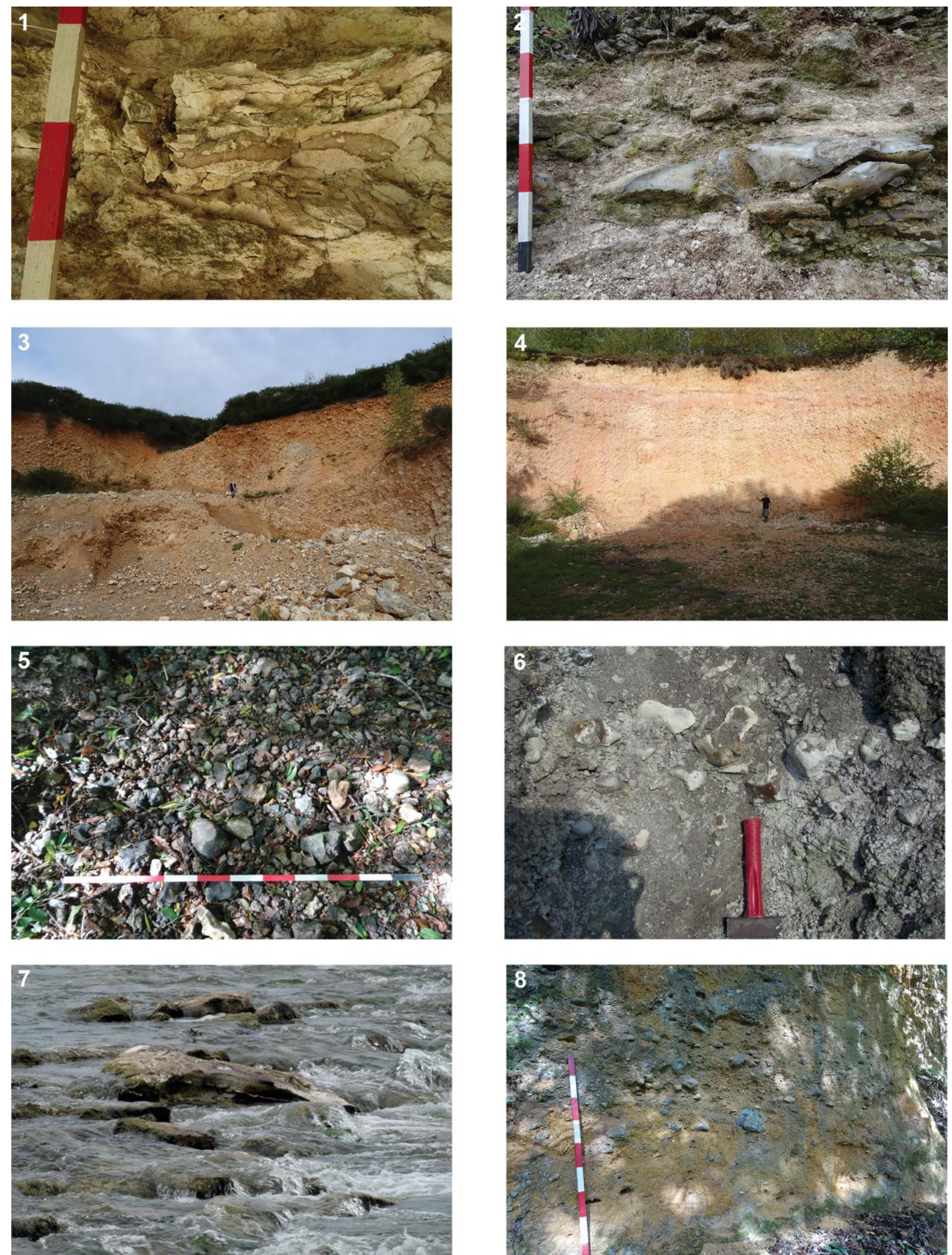

Figure 2. Some examples of regional primary and secondary outcrops. 1. Primary position: Le Firmament at Quincy (Cher); 2. Primary position: Les Fontaines Neuves at Chavannes (Cher); 3. Position of clay with flint: Le Fond des Bédus at Jars (Cher); 4. Position of clay with flint: La Riffauderie at Bannay (Cher); 5. Position of recent alluvials: Bellevue at Méry-es-Bois (Cher); 6. Colluvial position: La Musa at Meusnes (Loir-et-Cher); 7. Recent alluvial position: Le Clos Mailloux at Muides-sur-Loire (Loir-et-Cher); 8. Fossil alluvial position: Le Foulon at Beaulieu-sur-Loire (Loiret). 


\subsection{Proposed project outcomes}

Initiated in spring 2016, the PCR expands the interests of many previous researchers in elucidating the land use exploitation strategies of prehistoric human groups. Three main project areas were targeted:

1) Identifying current lithotheques, verifying their contents and adding to them if necessary. In theory, by archiving materials with the same evolutionary sequence demonstrated by their surficial characteristics, lithotheques will then faithfully represent the evolutionary chain specific to each SRO type.

2) Linking the principal depositional environments with the properties acquired by SRO through their geological history. This is central to our project. To better understand the mechanisms behind SRO evolution, we must understand and decipher the different phases of the evolutionary chain for each SRO type. This is achieved by using appropriate multi-faceted analysis.

3) Spreading knowledge and information amongst those within the PCR and with the wider archaeology community. This is best achieved by making an atlas of regional SRO types, mentoring field schools and sharing knowledge and data through free-access online GIS.

Our project is in harmony with other national research programs examining the mineral resource exploitation habits and territoriality of prehistoric human groups. Today, these topics are among the main issues occupying researchers studying Palaeolithic and Neolithic societies. In this context, the precise characterization of fixed resources, particularly the SRO which form the major part of most prehistoric assemblages, is of special interest because it allows traversed landscapes to be delimited and when coupled with the observable lithic technologies provides insight into the forms in which artefacts were transported. Such insights contribute to an interpretation of social structures, the mobility of human groups and possible interactions between separate cultural entities.

\section{Materials and methods}

A petro-archaeological lithic analysis cannot be satisfied merely by determining the stratigraphic origin or genetic type of a SRO, but rather must identify the formation from which it was collected by prehistoric humans; a formation which may be far distant from the primary deposit. If the classical method (e.g., Affolter 2002; Caux 2015; Mauger 1985; Masson 1981; Sanchez de la Torre et al. 2017a; Seronie-Vivien \& Seronie-Vivien 1987; Tomasso 2014) of identifying the genetic type of the SRO is unavoidable and necessary, the methodology must be extended to determine the gitological type. A powerful analytical tool useful in this instance is the study of the various alterations to which the SRO has been subjected.

Alterations may include induced silica dissolutions, transformation and precipitation because of silica solubility and a movement or flow of water around the SRO along with the possibility of water seeping through its core (Thiry et al. 2014). Alterations may be expressed at macroscopic, mesoscopic, microscopic and ultramicroscopic scales and generally an alteration develops a gradient from the outer surface inwards and away from the SRO's cortex. Analysis of surficial alterations recorded in siliceous rocks and artefacts is not new, having been studied by many archaeologists to determine the significance of patinas, glosses, changes related to displacement, variations of temperature and for several mineralogical transformations (Aubry 1975; Besançon 1982; Burroni et al. 2002; Cackler et al. 2000; Caspar et al. 2003; Coutard \& Ouzouf 2008; Curwen 1940; Glauberman \& Thorson 2012; Graetsch and Grünberg 2012; Hardaker 2012; Hewit 1915; Howard 2002; Hue 1929; Hurst and Kelly 1961; Journaux \& Coutard 1974; Levi-Sala 1986; Rottländer 1975; Stapert 1976; 
Thiry 1981; Vilas Boas 1975). These initial studies were the basis for the development of the concept of an evolutionary chain for SRO (Fernandes 2012; Fernandes et Raynal 2006; Fernandes et al. 2007, and forthcoming; Thiry et al. 2014). This concept is based on the concept that SRO are metastable in surficial environments and undergo transformations to their mineral structure and composition. These alterations occur each time the environment of the SRO changes during its geological and its archaeological history.

SRO can have a complex history before their collection by humans and they bear the scars of the different environments through which they passed. Flint sources can be separated into eight basic categories:

- primary sources;

- sub-primary sources;

- alteritic sources;

- colluviums;

- alluviums of an active or fossil river course;

- barrier beaches;

- moraines.

These eight basic categories can be modulated and combined in as many ways as necessary.

The same SRO may be found at different evolutionary stages in different deposits while different types of SRO may be found in the same depositional environment; for example, see Figure 3 where we find the gitological types F4d, F3d and F2d, an example of multiple secondary deposits. These types of deposits were extensively exploited in the Palaeolithic and are thus of considerable importance to archaeologists (e.g., Delvigne et al. 2014; Fernandes et al. 2006; Turq 2005). Identifying the specific criteria resulting from SRO immersion in these formations and clearly identifying the lithological diversity of these deposits is therefore of paramount importance in establishing a petro-archaeological perspective on objects derived therein.

By collecting the same type of SRO from the various sources in which it is found, that is from its primary position, from flinty clay, from colluviums and from alluviums, it is possible to identify its alterological profile gained from each environment through which it passed. Then it is possible to describe its evolutionary chain, link by link. Identifying the chronology of the stigmata carried by the surface of the samples and qualifying the mineralogical and micro-faciological changes received in the various deposits thus makes it possible to document the evolutionary chain of each type of SRO. 


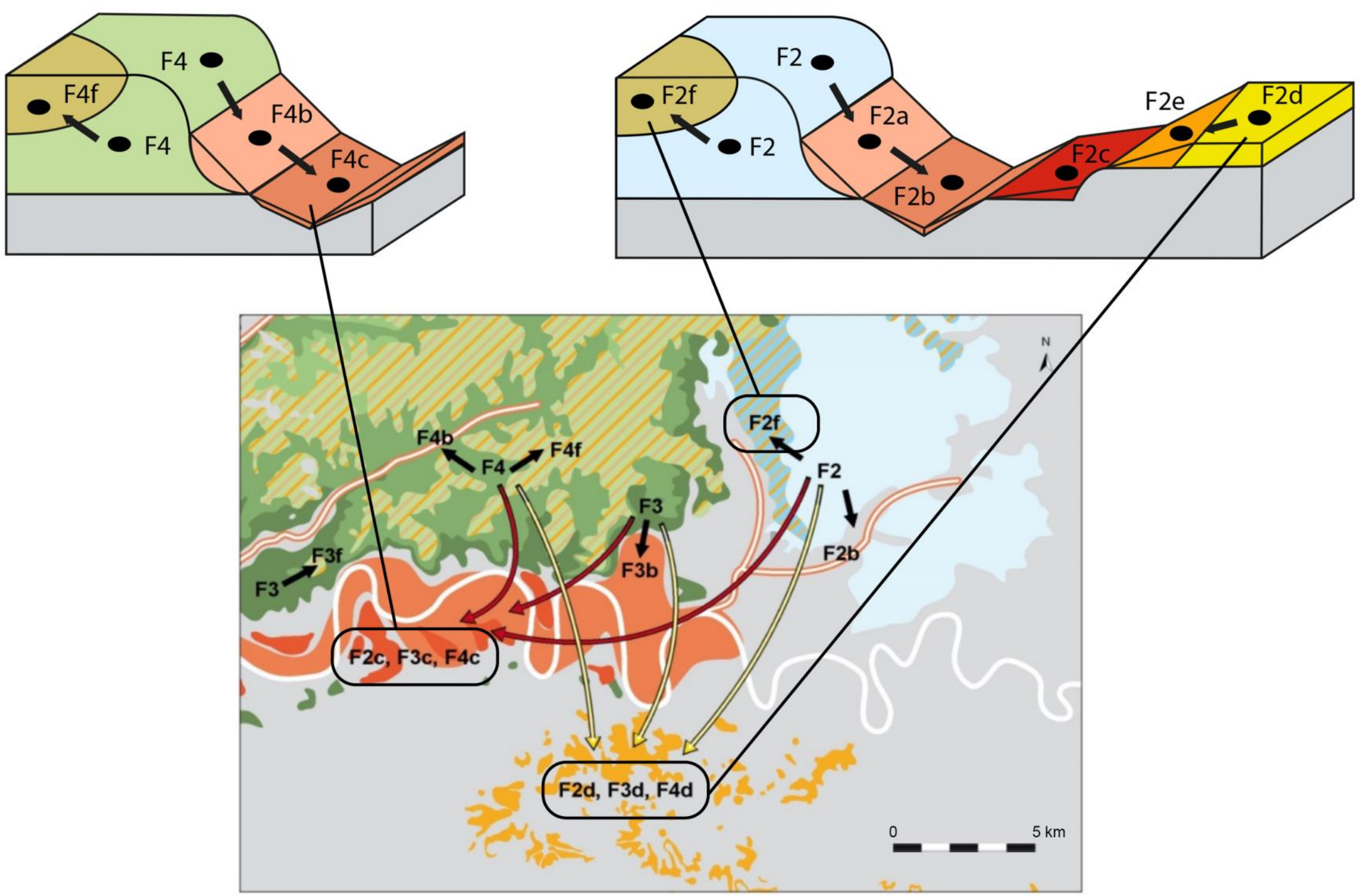

Figure 3. Theoretical view of the natural journey of a SRO. On top: block diagram; at the bottom: planimetric projection, different genetic types of SRO can found in the same secondary outcrops. Colors correspond to those of the international stratigraphic code: blue for Jurassic formations, green for Cretaceous formations, brown for alteritic formations and red, orange or yellow for Cenozoïc formations. 


\section{Results}

\subsection{New sampling protocol and survey form}

The first task of the PCR was to make an inventory of existing lithotheques since these reference collections, assembled by different researchers, are often under-exploited, unevenly constituted and rarely provide a list of the samples they contain. This initial step revealed a great heterogeneity of data, both in terms of quality and quantity. For example, of the 667 sampling points in the mid-Loire Valley, 426 are sources of Turonian flints. Sometimes a single locality was sampled several times by different researchers, none of whom had consulted previous documentation on the locality. Regarding the geographical coverage, we found that half of the sampling points were localized in two departments, Indre and Indre-etLoire, whereas in the lithotheques, no samples had been collected from the Eure-et-Loir department. To remediate this research bias, we developed a prospecting form, comprising 52 fields divided into eight categories, available in different electronic formats: -.xls, -.csv and .dbf, which can be used easily in the field regardless of whether internet connections are available or not. This form makes it possible to provide information compatible with existing Lithotheque data and easily integrates new survey data.

Content of the categories on the form:

\section{Administrative Information:}

1. key number (unique number given by the administrator);

2. author(s) creating the form (first name and last name);

3. author(s) modifying the form (first name and last name);

4. person(s) sampling (first name and last name);

5. sampling date;

6. date of creation of the form;

7. modification date;

8. source of the data (survey or inventory of existing lithotheque);

9. name of the program under which collection has operated.

\section{Administrative Information on the Lithotheque:}

10. full name of the lithotheque;

11. address of the lithotheque (number, street, town, postal code, country);

12. location in the storage place (free, depending on the lithotheque storage system);

13. inventory number in the lithotheque (according to local numbering system).

\section{Information on the Location of the Raw Material Source:}

14. source locality (name of the locality);

15. nearest town to the source (town name);

16. source department (department name);

17. source country (country name);

18. precise ' $\mathrm{X}$ ' coordinate of the source according to GPS or map (latitude in decimal degrees);

19. precise Y coordinate of the source according to GPS or map (longitude in decimal degrees);

20. precise altitude of the source (in meters);

21. X coordinate of the centroid of the town of the source (latitude in decimal degrees, if the precise $\mathrm{X}$ coordinate of the source is not known);

22. Y coordinate of the centroid of the town of the source (longitude in decimal degrees if the precise coordinate of the source is not known).

IV. Geological Information on the Deposit:

23. number and name of the geological map;

24. geological era to which the deposit belongs; 
25. geological series to which the deposit belongs;

26. geological stage to which the deposit belongs;

27. geological formation to which the deposit belongs;

28. comments on the method of determining the age of the deposit (free text);

29. lithology of the host rock (host rock name).

\section{Deposit Type:}

30. type of deposit (primary or secondary, if secondary specified which type);

31. form of outcrop (e.g., cliff, artificial cutting, mine, field, scree, and others);

32. position from which sample was collected (e.g., outcrop, scree, in the cliff, and others);

33. "endangered" character of the deposit (yes, no, indeterminate);

34. "exhausted" character of the deposit (yes, no, indeterminate);

35 . presence of an associated archaeological site (yes, no, indeterminate).

VI. Sample Information:

36. nature of the sample (e.g., SRO, sandstone, silicified limestone, jasper, and others);

37. sample shape of the (e.g., pebble, blocks, nodules, and others);

38. dimensional variability of the blocks (homo-metric or heterometric);

39. average dimensions of the blocks in centimetres;

40. minimum and maximum dimension of the blocks in centimetres;

41 descriptions of observable features (degree of knapping, presence of fractures, frost pitting, and others).

\section{Sampling Information:}

42. number of blocks collected (numerical value);

43. type of collection (systematic or selective);

44. presence or absence of documented polarity on the sample (yes, no).

VIII. Information on Associated Elements:

45. existence of a descriptive form (yes, no);

46. number of the existing descriptive form;

47. hypertext link to the descriptive form (filled in by the administrator);

48. existence of a photograph of the source (yes, no);

49. link to the photograph of the source with its legend (filled in by the administrator);

50. existence of a photograph of the sample (yes, no);

51. link to the photograph of the sample with legend (filled in by the administrator);

52. sample type (blocks, flakes, thin sections, and others).

\subsection{Raw material analyses}

As an example, we conducted work on the Upper Turonian of the southern Paris Basin, sampling 100 different locations in primary, alteritic and alluvial positions (the latter both recent and fossil). The sampling program enabled us to assemble a reliable representation of the variability of the flints from the Upper Turonian of Touraine, usually called "silex du Grand-Pressigny." The samples display different microfacies and reflect different formational environments throughout the study area (about $2500 \mathrm{~km}^{2}$ ). While they do contain many similar elements, such as pelloids, detrital quartz or benthic foraminifera of the Quinqueloculina genus, each individual type also contains specific elements making it possible to identify it in different secondary deposits (Delvigne et al. 2017; 2018). For example, the occurrence of Incertae sedis is typical of type D0018.3, whereas the large bryozoans have a classic occurrence in type D0018.4. Therefore, with a precise description of all the component elements making up the flint of the various genetic types of the Upper Turonian of Touraine, we can identify the different varieties in their secondary positions, and 
particularly in the multiple secondary deposits in which they are found, highlighting the gitological variability of the type.

To achieve this outcome, we developed a database using Microsoft Access containing more than 120 fields distributed across two forms (Fernandes et al. in preparation). The first form records information on the petrographic characteristics of SRO, that is, those characters derived from its genesis: e.g., rock structure, petro-fabric, abundance, sorting, roundness, sphericity, size and nature of each class of allochem, nature of the dominant orthochem; these provide the genetic type definition. The second form records the alterological data resulting from the pre-depositional alterations whose main characters are the colour inherited or acquired, ratio of the orthochems and of the allochems, description of the neocortex and of the sub-cortical band, color and intensity of the pre-depositional patina and the intensity of the pre-depositional gloss, the combination of which define the gitological type. This database, developed for the geological sample, is applied to the archaeological material through information recorded on two supplementary forms, the 'taphonomy' form containing information on the changes related to the post-depositional life of the SRO and a second sheet containing information about the use of the object which we call the 'traceology' form.

Following this analysis, an ID card is prepared for the different gitological types on which all the elements described in the Microsoft Access database are reproduced as text information augmented with photographs at various scales, usually macroscopic, mesoscopic and when possible microscopic and ultramicroscopic. We hope to develop a geochemical component to add to these ID cards. Once compiled, the ID card set will form an atlas of regional flint types.

\subsection{Integrated data in a GIS}

The goal of this approach is to gather and integrate data from the various disciplines concerned with the study of SRO into one database that includes the discriminating indicators for each type of material. The database that tabulates our research is linked to a geographical information system (GIS) that can be interrogated at ArcGIS Online.

Not only does the GIS display a layer showing the points that correspond to sampling locations, it also has a layer of polygons corresponding to the extent of the relevant geological formation defined by the geological maps. The sampling point link provides the basic information for the attribute table of the various formations and allows their extent to be verified (Fernandes et al. 2013; 2016). With rare exceptions, to have real value, a type definition requires the consideration of all the observations made on material from the same formation and not just information from one location taken alone.

Following a method tested in the Nouvelle-Aquitaine region, the formations are digitized with GIS software (such as QGIS or ArcGIS), using a WMS flow (Infoterre from the BRGM, including the geological maps scanned at 1:50000). Formations are displayed at a scale of 1:10000 and digitized with the same protocol for the regions already studied (Tallec 2015; Tuffery et al. 2017; in press). Since the attribute table of the SRO formations is the same for everyone using it, all project team members can use the same method for describing and comparing the attribute data. The shape files created are centralized by a nominated researcher and downloaded to the ArcGIS server where they can be searched by any member of the lithotheques review projects (PCR).

The strength of this GIS lies in the combination of the different layers of referenced data:

1) the SRO formations as described above,

2) integrated data about the deposits through the forms described above and,

3) ID cards for each gitological type, produced from the integrated data that includes the concept of the evolutionary chain of SRO (above). 
This GIS, already produced for the regions of southern mid-Loire, Nouvelle Aquitaine (between Dordogne and Lot) and Auvergne-Rhône-Alpes, not only allows a large amount of data to be processed like ascertaining relationships between geological entities, lithological potential of certain localities and hydrographic networks, but also allows online sharing with other interested researchers (Figure 4).

\section{Discussion and conclusions}

\subsection{Discussion}

The development of an integrated methodology that considers the concept of an evolutionary chain for SRO is an analytical asset of primary importance. Such a methodology makes it possible to contextualize, verify and understand precisely the different textural, mineral and micro-facies transformations undergone by SRO during their travels from outcrop to archaeological site. The lithotheque thus becomes a powerful and dynamic archaeologist's resource based on systematic analytical techniques rather than being the result of a random collection of lithic materials.

Our analytical methodology has been developed for application in the field and in the laboratory at macroscopic, mesoscopic, microscopic and ultramicroscopic levels. We also want to incorporate into this project aspects of geochemistry and the physical composition of SRO. This addition will contribute to the procedures used for identifying the chemical evolution of SRO similar to what some of us developed for the so-called Campanian Bergerac flint of Nouvelle Aquitaine and the Obourg flint from Hainault (Fernandes et al. in press). This will also enable us to enhance the chemical aspect of the ID card for the various gitological types in the same way that Sanchez de la Torre (2015) and Ortega et al. (2017) have done for SRO resources in Catalonia. Although the importance of geochemistry in the study of materials is widely proven it must take place following the precise determination of the naturalist characteristics (Sanchez de la Torre et al. 2017a; 2017b), since routine geochemical analysis is not suitable for SRO because of their open and metastable nature (Delvigne et al. 2017; Fernandes 2012, Thiry et al. 2014).

The many integrated data sources, displayed in the GIS as different layers, allows for integrated operability of the method and researchers can progress at different speeds simultaneously, without slowing down the overall development of the project. It is thus possible to carry out work in parallel, like drawing formations that correspond to a shape file polygon, carrying out fieldwork and verifying the extent of the formations by completing the field file (in the GIS as a point layer), and carrying out SRO type diagnoses to initialize the ID card (found in the GIS as a .pdf file associated with the two previous layers by a hypertext link).

Knowledge pooling increases in importance in prehistoric archaeology as more studies appear that are based on recognizing lithic raw material sources from which are drawn models of prehistoric territories or palaeo-demographies. However, if the basic data is biased or partial, due to extra-local materials not being recognized (the well-known "indeterminate flints" category), a situation arises where the diminished litho-space fails to represent the true extent of the exploited territory. Understanding the lithological diversity of a particular area also reflects on the acquisition of raw materials because it seems that only by knowing the quantity, diversity and the mode of introduction of raw materials arriving into an archaeological site from coherent geotopes, can one draw conclusions about occupational frequency. Hence the importance of:

1) a methodology used to characterize the various raw materials; and

2) knowledge of the diversity of SRO types outcropping in as large an area as possible. 


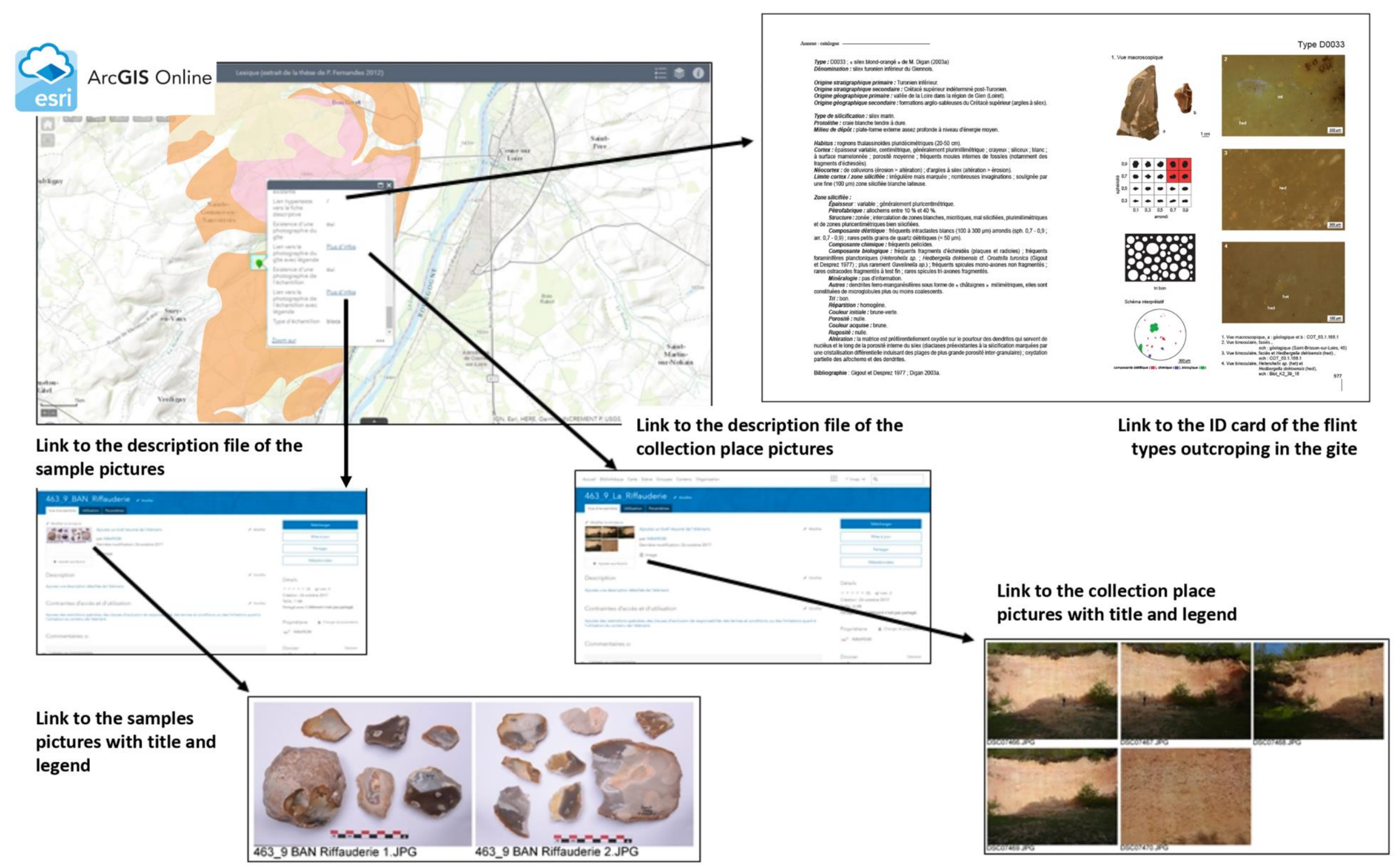

Figure 4. Excerpt from the GIS. Attribute data of the secondary deposit of La Riffauderie at Banay (Cher) and the descriptive card of type D0033 found in this place. 
In the mid-Loire Valley region, the online data accessibility of the $P C R$ enriches the archaeo-material knowledge pool, both fundamentally through descriptions of the SRO evolutionary chain mechanisms and practically by providing ID cards for different types of flint.

The project also contains a heritage dimension that has potential to preserve raw material source localities. We observed when making our inventory of lithotheques, that sampling took place on multiple occasions at the same locality; our project eliminates such destruction and is of special importance when deposits exploited by prehistoric humans outcrop over small surface areas of perhaps a few tens of meters square like the Portlandian marine flints at "La Loumas" (Orville, Indre) or the Eocene silcretes at Les "Fontaines neuves" (Chavannes, Cher) whose existence is threatened. Even larger formations may be under threat as demonstrated by the diminished size of the flint blocks of the Upper Turonian of Touraine (the "GrandPressigny") found today that are much smaller than those identified by the prehistorians of the early to mid-twentieth century. This situation is partly due to intense modern exploitation by professionals and amateurs from all over Europe who collect this flint as raw material for experimental knapping and to enrich institutional and private lithotheques.

\subsection{Conclusions}

The purpose of this paper was to present a review of the "Réseau de lithothèques en région Centre-Val de Loire" project and to describe the methodological foundations of our multi-faceted approach. Briefly, the identification of collected locations must include the evolutionary chain of SRO concept, a source inventory that is as complete as possible, a description of discriminating characteristics according to the types of superficial formations and an online GIS grouping of all these data incorporated into a single database.

We have attempted to demonstrate the importance of inter-relationships between, and homogenization of, protocols and methodologies in data acquisition and sharing. The degree of collaboration achieved by the PCR in sharing knowledge is made simple today thanks to computer tools that allow work to proceed simultaneously and at different rhythms in scattered locations. These technological advances contribute to the value of the PCR as an experimental laboratory.

The "Réseau de lithothèques en région Centre-Val de Loire" project is closely associated with similar programs already operating in France, especially those in Auvergne-Rhône-Alpes and Nouvelle Aquitaine. The ultimate objective is to build a national and international community around a common project - i.e., the research group (GDR) Silex -, bringing participants together regularly to share knowledge and understanding that goes beyond individual initiatives.

\section{Acknowledgements}

This work has been funded by the French Ministry of Culture and Communication with the support of the Conservateur regional de l'Archéologie, S. Révillion. In addition to all the organizers of the 11th international symposium on knappable materials, "From toolstone to stone tools", held in Buenos Aires (Argentine) from 07 to 12 November 2017, we would like to thank the members of the PCRs "Réseau de lithothèque en région Centre-Val de Loire" "Réseau de lithothèque en région Nouvelle-Aquitaine" and "Réseau de lithothèque en région Auvergne-Rhône Alpes", as well as the board members who participated in the elaboration of the GDR "Silex" for discussions and advice that enriched our reflections and V. Rots and all the member of the Traceolab of Liège for the access to microscopy equipment. Finally, we thank the reviewers of this paper who improved its quality. Translation and revision by P. Bindon. 


\section{References}

Affolter, J. 2002, Provenance des silex préhistoriques du Jura et des régions limitrophes. Archéologie neuchâteloise Vol. 28. Service et musée cantonal d'archéologie, Neuchâtel, 341 p. (in French) ("Provenance of prehistoric flints of Jura and neighboring regions")

Aubry M.-P. 1975, Recherches sur la nanopétrographie des roches siliceuses. Bulletin trimestriel de la Société géologique de Normandie, 62(2): 7-34. (in French) ("Research on nanopetrography of siliceous rocks")

Aubry, T. 1991, L'exploitation des ressources en matières premières lithiques dans les gisements solutréens et badegouliens du bassin versant de la Creuse (France). Ph.D. Thésis. Université Bordeaux 1, Talence, 327 p. (in French) ("Exploitation of lithic raw material resources in the Solutrean and Badegoulian sites of the Creuse watershed (France)")

Aubry, T. 2015, Retour aux sources: le silex au Paléolithique supérieur en région Centre. Archéologie du Val de Creuse en Berry, 6: 113-124. (in French) ("Back to roots: Upper Palaeolithic flints in the Center region")

Aubry, T. \& Walter, B. 2003, Reconstitution des modalités d'approvisionnement et de diffusion des matières premières lithiques pendant le Paléolithique supérieur - l'apport du site solutréen et badegoulien des Maîtreaux (Indre et Loire, France). In: Les matières premières lithiques en Préhistoire, actes de la table ronde internationale d'Aurillac. (Surmely F., Ed.), Association de préhistoire du Sud-Ouest, Cressensac: p. 41-50. (in French) ("Reconstitution of the supply and distribution modes of the lithic raw materials during the Upper Palaeolithic. The contribution of the Solutrean and Badegoulian site of Les Maîtreaux (Indre et Loire, France)")

Besançon, J. 1982, Les figures d'altération des silex du Liban et leurs implications. In: Archéologie au Levant. Recueil à la mémoire de R. Saidah (Jean Pouilloux, J., Ed.). Série archéologique Vol. 12, Maison de l'Orient et de la Méditerranée, Lyon: p. 21-32. (in French) ("Flint alteration figures from Lebanon and their implications")

Burroni, D., Randolph, E., Donahue, R. \& Pollard, A.M. 2002, The surface features of flint artefacts as a record of environmentals processes. Journal of Archaeological Science, 29: 1277-1287, doi:10.1006/jasc.2001.0771

Cackler, P.R., Glascock, M. D., Neff, H. \& Chiarulli, B.M. 2000, Effects of weathering on the coloration of chert and its implications for provenance studies. Lithic Technology, 24(2): 81-90, doi:10.1080/01977261.1999.11720949

Caspar J.-P., Masson, B. \& Vallin, L. 2003, Poli de bois ou poli de glace au Paléolithique inferieur et moyen? Problèmes de convergence taphonomique et fonctionnelle. Bulletin de la Société préhistorique française, 100(3): 453-462. (in French) ("Wood or ice polishes in the lower and middle Palaeolithic? Problems of taphonomic and functional convergence") doi:10.3406/bspf.2003.12866

Caux, S. 2015. Du territoire d'approvisionnement au territoire culturel. Pétroarchéologie et techno-économie du silex Grain de mil au cours de l'Aurignacien dans le Sud-ouest de la France. Ph.D. Thésis. Université de Bordeaux, Talence, 249 p. (in French) ("From the supply territory to the cultural territory. Petroarchaeology and techno-economics of "Grain de Mil » flint during the Aurignacian in southwestern France")

Chabas, F. 1874, Les silex de Volgu. Rapport à la société d'Histoire et d'archéologie de Chalon-sur-Saône. Châlon-sur-Saône, 24 p. (in French) ("Flints from Volgu”) 
Charbonnier, O. 1962, L'abri aurignacien des Roches, Commune de Pouligny-Saint-Pierre (Indre). L'Anthropologie, 66(5-6): 469-484. (in French) (“Aurignacian Les Roches rockshelter, Pouligny-Saint-Pierre (Indre)")

Cordier, G. 1956, Le vrai visage du Grand-Pressigny. In: Comptes rendus du XVème Congrès préhistorique de France (Poitiers-Angoulême, 15-22 juillet 1956). Société préhistorique française, Paris: p. 416-442. (in French) ("The true face of Le Grand-Pressigny")

Coutard, J.-P. \& Ozouf, J.-C. 2008, Nouvelle approche de l'altération des galets de silex dans les dépôts marins Pléistocènes: contribution à l'étude des plates-formes marines du val de Saire (Normandie, France). Quaternaria, 19(4): 335-344. (in French) ("New approach to the alteration of flint pebbles in Pleistocene marine deposits: Contribution to the study of the marine platforms of the Val de Saire (Normandy, France)") doi:10.1016/j.earscirev.2014.05.008

Curwen, E. C. 1940, The white patination of black flint. Antiquity, 14: 435-437, doi:10.1017/S0003598X0000449X

Debrand-Passard, S. 1982, Le Jurassique supérieur du Berry: sud du Bassin de Paris, France. Mémoire BRGM Vol. 118. Bureau de recherches géologiques et minières, Orléans, 227 p. (in French) ("Upper Jurassic from Berry: South of the Paris Basin, France")

Delcourt-Vlaeminck, M. 1998, Le silex du Grand-Pressigny dans le Nord-ouest de l'Europe: le silex tertiaire, concurrent possible du Grand-Pressigny? Ph.D. Thésis. École des hautes études en science sociale, Paris, 449 p. (in French) ("Grand-Pressigny flints in Northwestern Europe: Tertiary flints, a possible challenger for the Grand-Pressigny")

Delvigne, V. 2016, Géoressources et expressions technoculturelles dans le sud du Massif central au Paléolithique supérieur: des déterminismes et des choix. Ph.D. Thésis. Université de Bordeaux, Talence, 1297 p. (in French) ("Georessources ans technocultural expressions in the south of the french Massif Central during the Upper Palaeolithic: Determinisms and choices")

Delvigne, V., Fernandes, P., Piboule, M., Lafarge, A., Geneste, J.-M., Moncel, M.-H. \& Raynal, J.-P. 2014, Ressources en silex au Paléolithique supérieur dans le Massif central: réseaux locaux et approvisionnements lointains revisités. In: Modes de contacts et de déplacements au Paléolithique eurasiatique, actes du colloque international de la commission 8 de l'UISPP. (Otte, M. \& Le Brun-Ricalens, F., Eds.) Eraul, Liège and ArchéoLogiques, Luxembourg: p. 403-435. (in French) ("Upper Palaeolithic flint resources in the Massif Central: Local networks and distant supplies revisited")

Delvigne, V., Fernandes, P., Piboule, M., Lafarge, A. \& Raynal, J.-P., 2017, Circulation de géomatières sur de longues distances au Paléolithique supérieur: le cas des silex du Turonien du sud du Bassin parisien. Comptes rendus Palevol, 16(1): 82-102. (in French) ("Circulation of geomaterials over long distances in the Upper Palaeolithic: The case of the Turonian flints of the southern Paris Basin") doi:10.1016/j.crpv.2016.04.005

Delvigne, V., Piboule, M., Fernandes, P., Lafarge, A., Primault, J., Aubry, T., Mangado, X. \& Raynal, J.-P. 2018, Principales matières premières lithiques disponibles au Paléolithique entre le Bassin parisien et l'Auvergne: partie 2 - Loir-et-Cher, Indre-et-Loire. Le cas du Turonien inférieur et supérieur. In: Préhistoire de la France centrale. Actualité de la recherche, actes du colloque interrégional de Montluçon (Troubat O., Ed.). Cercle d'Archéologie de Montluçon et de la région, Montluçon: p. 27-48. (in French) ("Main lithic raw materials available in the Palaeolithic between the Paris Basin and Auvergne: Part 2 - Loir-et-Cher, Indre-et-Loire. The case of the Lower and Upper Turonian”) 
Fernandes, P. 2012, Itinéraires et transformations du silex: une pétroarchéologie refondée, application au Paléolithique moyen. Ph.D. Thésis. Université Bordeaux-1, Talence, 623 p. (in French) ("Flint Transformations: A Revised Petro-archaeology. Application to the Middle Palaeolithic")

Fernandes, P. \& Raynal, J.-P. 2006, Pétroarchéologie du silex: un retour aux sources. Comptes Rendus Palevol, 5: 829-837. (in French) ("Petro-archaeology of flints: Back to roots") doi:10.1016/j.crpv.2006.04.002

Fernandes, P., Raynal, J.-P. \& Moncel, M.-H. 2006, L’espace minéral au Paléolithique moyen dans le Sud du Massif central: premiers résultats pétroarchéologiques. Comptes Rendus Palevol, 5: 981-993. (in French) ("Mineral space in the Middle Palaeolithic in the southern Massif Central: Preliminary petro-archaeological results")

Fernandes, P., Le Bourdonnec, F.X., Raynal, J.-P., Poupeau, G., Piboule, M. \& Moncel, M.H. 2007, Origins of prehistoric flints: The neocortex memory revealed by scanning electron microscopy. Comptes Rendus Palevol, 6: 557-568, doi:10.1016/j.crpv.2007.09.015

Fernandes, P., Delvigne, V., Dubernet, S., Le Bourdonnex, F.-X., Morala, A., Moreau, L., Piboule, M., Turq, A. \& Raynal, J.-P. in press, Flint studies revisited: The "chaîne évolutive" concept. In: Reports of the 7th international conference of the UISPP Commission on Flint Minning in Pre- and Protohistoric Times. Mons and Spienne (Collet H., Hauzeur A. \& Bostyn F., Eds.). Service de Publication de Wallonie, Namur, $7 \mathrm{p}$.

Fernandes, P., Raynal, J.-P., Tallet, P., Tuffery, C., Piboule, M., Seronie-Vivien, M., SeronieVivien, M.-R., Turq, A., Morala, A., Affolter, J., Millet, D., Millet, F., Bazile, F., Schmidt, P., Foucher, P., Delvigne, V., Liagre, J., Gaillot, S., Morin, A., Moncel, M.-H., Garnier, J.-F. \& Leandry-Bressy, C. 2013, Une carte et une base de données pour les formations à silex du sud de la France: un outil pour la pétroarchéologie. Paléo, 24: 219-228. (in French) ("A map and a database for flint formations in the south of France: A tool for petro-archaeology") URL: http://journals.openedition.org/paleo/2864

Fernandes, P., Tuffery, C., Binder, D., Leandri-Bressy, C., Bracco, J.-P., Tallet, P., Morala, A., Turq, A., Davitian, G., Caverne, J.-B., Dalphinet, D., Delvigne, V., Liagre, J., Gaillot, S., Millet, D., Millet, F., Piboule, M., Picavet, R., Schmidt, P., Tomasso, A., Affolter, J., Bazile, F., Garnier, J.-F., Bintz, P., Pinçon, G. \& Raynal, J.-P. 2016, Constitution d'une base de données géoréférencées sur les formations à silex dans le sud de la France. Une démarche collaborative. In: Ressources lithiques, productions et transferts entre Alpes et Méditerranée (Binder D., Ed.). Société préhistorique française, Paris: p. 137-152. (in French) ("Creation of a georeferenced database on flint formations in the south of France. A collaborative approach")

Fontana, L. 2005, Territoires, mobilité et échanges au Magdalénien dans l'Aude et la Massif central (France): approche comparative, modélisation et perspectives. In: Territoires, déplacements, mobilités, échanges durant la Préhistoire. Terres et Hommes du Sud, actes des 126ème congrès nationaux des Sociétés historiques et scientifiques (Jaubert J. and Barbaza M.). Comité des Travaux Historiques et Scientifiques, Paris: p. 355-370. (in French) ("Territories, mobility and exchanges in the Magdalenian Aude and Massif Central (France): Comparative approach, modeling and perspectives") 
Fontana, L., Aubry, T., Chauviere, F.-X., Digan, M., Mangado Llach, J., Petit, C. \& Teurquety, G. 2018, Système économique et mobilité des chasseurs-collecteurs du Massif central au Paléolithique supérieur : un état de la question. In: Préhistoire de la France centrale. Actualité de la recherche, actes du colloque interrégional de Montluçon. (Troubat O., Ed.). Cercle d'Archéologie de Montluçon et de la région, Montluçon: p. 103-120. (in French) ("Economic system and mobility of hunter-gathers from the Massif Central during the Upper Palaeolithic: A state of the question")

Gardez, H. 1933, Étude sur la concurrence des silex de Spiennes (Belgique), à ceux du GrandPressigny (Indre-et-Loire), dans le Nord du Département de l'Aisne, et sépulture dolménique de Flavigny-le-Petit. Bulletin de la Société préhistorique française, 30(4): 270-272. (in French) ("Study on the competition of flint from Spiennes (Belgium) and those of Grand-Pressigny (Indre-et-Loire), in the North of the Department of Aisne, and dolmenic burial of Flavigny-le-Petit")

Giot, D., Mallet, N. \& Millet, D. 1986, Les silex de la région du Grand-Pressigny. Recherche géologique et analyse pétrographique. Revue Archéologique du Centre de la France, 25(1): 21-36. (in French) ("Flints of the Grand-Pressigny region. Geological research and petrographic analysis") doi:10.3406/racf.1986.2460

Giraud, E. 1955, Trois poignards en silex du Grand-Pressigny. Bulletin de la Société préhistorique française, 52(8): 464-464. (in French) ("Three flint daggers in GrandPressigny flints") doi:10.3406/bspf.1955.3242

Glauberman, P.J. \& Thorson, R.M. 2012, Flint Patina as an Aspect of "Flaked Stone Taphonomy": A Case Study from the Loess Terrain of the Netherlands and Belgium. Journal of Taphonomy, 10(1): 21-43. URL: https://dialnet.unirioja.es/servlet/articulo?codigo $=4983226$

Graetsch, H.A. \& Grünberg, J.M. 2012, Microstructure of flint and other chert raw materials. Archaeometry, 54(1): 18-36. doi:10.1111/j.1475-4754.2011.00610.x

Gratier, M. 1977a, Les stations acheuléo-moustériennes de Moulins-sur-Céphons (Indre). Première partie. Revue Archéologique du Centre de la France, 16(1-2): 71-84. (in French) ("The Acheuléo-Mousterian stations of Moulins-sur-Cephons (Indre). First part") doi:10.3406/racf.1977.2076

Gratier, M. 1977b, Les stations acheuléo-moustériennes de Moulins-sur-Céphons (Indre). Deuxième partie. Revue Archéologique du Centre de la France, 16(3-4): 295-306. (in French) ("The Acheuléo-Mousterian stations of Moulins-sur-Cephons (Indre). Second part”) doi:10.3406/racf.1977.2103

Gratier, M. \& Macaire, J.-C. 1978, Les ateliers acheuléens des buttes de Gron (Cher). Bulletin de l'Association française pour l'étude du Quaternaire, 15(4): 161-169. (in French) ("The acheulean workshops of the Buttes de Gron (Cher)") doi:10.3406/quate.1978.1336

Hardaker, T. 2012, The artefacts from the present land surface at the Palaeolithic site of Warren Hill, Suffolk, England. Proceeding of the Geologists' Association, 123(5): 692713., doi:10.1016/j.pgeola.2012.05.009

Hewitt, H.D. 1915, Some experiments on patination. Proceedings of the Prehistoric Society of East Anglia, 2(1): 45-51, doi:10.1017/S0958841800023334

Howard, C.D. 2002, The Gloss Patination of Flint Artifacts. Plains Anthropologist, 47(182): 283-287, doi:10.1080/2052546.2002.11932098 
Hue, E. 1910, Distribution géographique de l'industrie en silex du Grand-Pressigny. In: Congrès de la Société préhistorique de France, comptes rendus de la sixième session. Société préhistorique française, Paris: p. 390-436. (in French) ("Geographical distribution of lithic industry made in Grand Pressigny flints")

Hue, E. 1929, Recherches sur la patine des silex. Bulletin de la Société préhistorique française, 26(9): 461-468. (in French) ("Reasearch on flint patina") doi:10.3406/bspf.1929.12098

Hurst, V.J. \& Kelly, A.R. 1961, Patination of cultural flints. Science, 134(3474): 251-256, doi:10.1126/science.134.3474.251

Irribarria, R. 1992, La diffusion de l'opalite dans les pays de Loire moyenne: état de la question en 1992. Mémoire de DEA, université de Paris I Panthéon-Sorbonne, Paris, 59 p. (in French) ("The spread of opalite in the Middle Loire valley: State of affairs in 1992”)

Journaux, A. \& Coutard, J.-P. 1974, Expérience de thermoclastie sur des roches siliceuses. Bulletin du Centre de Géomorphologie de Caen, 18: 7-20. (in French) ("Thermoclastic experiment on siliceous rocks")

Kildea, F. 2008, La Croix de Bagneux à Mareuil-sur-Cher (Loir-et-Cher). Un site paléolithique à occupations multiples dans la vallée du Cher. (Rapport final d'opération de fouille archéologique préventive, INRAP). Unpublished report for the Direction régionale des affaires culturelles du Centre, Orléans, 643 p. (in French) ("La Croix de Bagneux at Mareuil-sur-Cher (Loir-et-Cher). A Palaeolithic site with multiple occupations in the Cher Valley")

Klaric, L., Liard, M., Bertran, P., Dumarçay, G., Araujo Igreja, M., Aubry, T., Walter, B. \& Regert, M. 2011, La Picardie (Preuillysur-Claise, Indre-et-Loire): neuf ans de fouille sur un gisement rayssien finalement pas si mal conservé ! In: À la recherche des identités gravettiennes: actualités, questionnements et perspectives: actes de la table ronde sur le Gravettien en France et dans les pays limitrophes, Aix-en-Provence, 6-8 octobre 2008. (Goutas N., Klaric L., Pesesse D., Eds.), Société préhistorique française, Paris: p.291310. (in French) ("La Picardie (Preuillysur-Claise, Indre-et-Loire): Nine years of excavation on a Rayssian site not so poorly preserved!")

Lablanche, G. 1982, Les calcaires lacustres paléogènes de la Champagne berrichonne: étude cartographique et pétrographique, reconstitution du milieu de sédimentation. Les documents du BRGM 49. BRGM, Orléans, 127 p. (in French) ("Palaeogenic lacustrine limestones of the Berry region: Cartographic and petrographic study, reconstitution of the sedimentation medium")

Lethrosne, H. \& Despriee, J. 2014. Minières à silex et ateliers de façonnage de haches dans la vallée du Loir vendômois, l'exemple de Pezou « La Chenevière-Dieu » (Loir-et-Cher).

In: Zones de production et organisation des territoires au Néolithique. Espaces exploités, occupés, parcourus. Actes du 30ème colloque interrégional sur le Néolithique. (Louboutin C., Verjux C., Eds.), ARCHEA-FERACF (Archéa - Fédération pour l'édition de la revue archéologique du centre de la France), Tours: p. 103-116. (in French) ("Flint mining and axes shaping workshops in the Loir valley, the example of Pezou "La Chenevière-Dieu" (Loir-et-Cher)")

Levi Sala, I. 1986, Use Wear and Post-Depositional Surface Modification: A word of caution. Journal of Archaeological Science, 13(3): 229-244, doi:10.1016/0305-4403(86)90061-0 
Lorenz, J. 1992, Le Dogger du Berry: contribution à la connaissance des plates-formes carbonatées européennes du Jurassique. Les documents du BRGM Vol. 212. BRGM, Orléans, 397 p. (in French) ("The Dogger of Berry: Contribution to the knowledge of European carbonate platforms of Jurassic")

Mallet, N. 1992, Le Grand-Pressigny. Ses relations avec la civilisation Saône et Loire. Les amis du musée du Grand-Pressigny, Le Grand-Pressigny, 218 p. (in French) ("Le Grand Pressigny. His relations with Saône et Loire civilization")

Mallet, N. 2001, De la détermination des silex du Grand-Pressigny. Bulletin des Amis du Musée du Grand-Pressigny, 52: 17. (in French) ("The determination of the flints of Grand-Pressigny")

Masson, A. 1981, Pétroarchéologie des roches siliceuses, intérêt en Préhistoire. Ph.D. Thesis. Université de Lyon, Lyon, 101 p. (in French) ("Petroarchaeology of siliceous rocks, interest in prehistory")

Masson, A. 1986, Nouvelles contributions aux études pressigniennes. Revue Archéologique de l'Ouest, Supplément 1:11-120. (in French) ("New contributions to pressignian studies")

Mauger, M. 1985, Les matériaux siliceux utilisés au Paléolithique supérieur en Île-deFrance. Ph.D. Thesis. Université Paris 1 Panthéon - La Sorbonne, Paris, 406 p. (in French) ("The siliceous raw materials used in the Upper Palaeolithic in Île-de-France")

Mouhsine, S. 1994, Processus de la silicification sédimentaire. Modèle du Turonien de Touraine. Ph.D. Thesis. Museum national d'Histoire naturelle, Paris, 118 p. (in French) ("Sedimentary silicification process. Turonian model of Touraine")

Munck, E. 1928, Note sur l'aspect et la patine des silex de la région du Grand-Pressigny (Indre-et-Loire). Bulletin de la Société d'Anthropologie de Bruxelles, 43: 247-249. (in French) ("Note on the appearance and patina of flint in the region of Grand-Pressigny (Indre-et-Loire)")

Ortega, D., Roque, C., Ibanez, J., Beamud, E., Larrasoana, J.C., Saez, A. \& Terradas, X. 2017, The chert from the Castelltallat Formation (south-central Pyrenees): Archaeometric characterisation and archaeological implications. Archaeological and Anthropological Sciences, doi:10.1007/s12520-016-0458-1

Person, A., Tourenq, J. \& Trochon, T. 1994, Sépiolite et silicifications, indicateurs de paléoenvironnement lacustre au sommet des calcaires cénozoiques du Berry (Bassin de Mehun-sur-Yèvre, Cher). Géobios, 27(1): 293-305. (in French) ("Sepiolite and silicification, lacustrine palaeoenvironment indicators at the top of the Cenozoic limestones of Berry (Mehun-sur-Yèvre Basin, Cher)") doi:10.1016/S00166995(94)80046-4

Piboule, M., Delvigne, V., Fernandes, P., Lafarge, A. \& Raynal, J.-P. 2018, Principales matières premières lithiques disponibles au Paléolithique entre Bassin Parisien et l'Auvergne: partie 1 - Allier, Cher et Indre. Grandes variétés des matériaux et leurs transits au Paléolithique ancien et moyen. In: Préhistoire de la France centrale. Actualité de la recherche, actes du colloque interrégional de Montluçon. (Troubat O., Ed.). Cercle d'Archéologie de Montluçon et de la région, Montluçon: p. 9-26. (in French) ("Main lithic raw materials available in the Palaeolithic between Paris Basin and Auvergne: Part 1 - Allier, Cher and Indre. Large varieties of materials and their transits in the ancient and middle Palaeolithic") 
Pomerol, F. 1888, L'abri sous roche de Blanzat. In: Compte rendu de la XVIIIème session du congrès de l'Association Française pour l'Avancement des Sciences. Association Française pour l'Avancement des Sciences, Paris: p. 637-640. (in French) ("The Blanzat rockshelter")

Primault, J. 2003a, Exploitation et diffusion des silex de la région du Grand-Pressigny au Paléolithique. Ph.D. Thesis, Université Paris X, Nanterre, 358 p. (in French) ("Exploitation and diffusion of flint from the Grand Pressigny region during the Palaeolithic")

Primault, J. 2003b, Exploitation et diffusion des silex de la région du Grand-Pressigny au Paléolithique. In: Les matières premières lithiques en Préhistoire, actes de la table ronde internationale d'Aurillac. (Surmely F., Ed.), Association de préhistoire du SudOuest, Cressensac: p. 283-292. (in French) ("Exploitation and diffusion of flint from the Grand Pressigny region during the Palaeolithic")

Rottländer, R. 1975, The formation of patina on flint. Archaeometry, 17(1): 106-110. doi:10.1111/j.1475-4754.1975.tb00120.x

Saint-Venant (de), J. 1891, L'industrie du silex en Touraine dans les temps préhistoriques et la dissémination de ses produits. Mémoire de la Société Archéologique de Touraine, 36: 269-284. (in French) ("The flint industry in Touraine during prehistoric times and the dissemination of its products")

Saint-Venant (de), J., 1910, Enquête du congrès sur la distribution géographique de l'industrie en silex du Grand-Pressigny. In: Congrès de la Société préhistorique de France, comptes rendus de la sixième session. Société préhistorique française, Paris: p. 390-436. (in French) ("Survey on the geographical distribution of the flint industry of GrandPressigny")

Sanchez de la Torre, M., Le Bourdonnec, F.-X., Gratuze, B., Domingo, R., Garcia-Simon, L.M., Montes, L., Mazod, C. \& Utrilla, P. 2017a, Applying ED-XRF and LA-ICP-MS to geochemically characterize chert. The case of the Central-Eastern Pre-Pyrenean lacustrine cherts and their presence in the Magdalenian of NE Iberia. Journal of Archaeological Science Report, 13: 88-98, doi:10.1016/j.jasrep.2017.03.037

Sanchez de la Torre, M., Le Bourdonnec, F.-X. \& Gratuze, B. 2017b, Reconsidering prehistoric chert catchment sources: New data from the Central Pyrenees (Western Europe). Archaeological and Anthropological Sciences, 11(3):947-957. doi:10.1007/s12520-017-0581-7

Seronie-Vivien, M. \& Seronie-Vivien, M.-R. 1987, Les silex du Mésozoïque nord-aquitain. Approche géologique de l'étude des silex pour servir à la recherche préhistorique. Société linnéenne de Bordeaux, Bordeaux, 136 p. (in French) ("Flints of the NorthAquitaine Mesozoic. Geological approach to the study of flint for use in prehistoric research")

Stapert, D. 1976, Some natural surface modifications on flint in the Nethe, Netherlands. Palaeohistoria, 18: 7-42. 
Surmely, F., Barrier, P., Bracco, J.-P., Charly, N. \& Liabeuf, R. 1998, Caractérisation des matières premières siliceuses par l'étude des microfaciès et application à la connaissance du peuplement préhistorique de l'Auvergne. Comptes Rendus de l'Académie des Sciences, 326: 595-601. (in French) ("Characterization of siliceous raw materials by the study of microfacies and application to the knowledge of the prehistoric settlement of Auvergne") doi:10.1016/S1251-8050(98)80212-7

Surmely, F. 2000, Le peuplement magdalénien de l'Auvergne. In: Le Paléolithique supérieur récent: Nouvelles données sur le peuplement et l'environnement, actes de la table ronde de Chambéry. (Pion G., Ed.), Société préhistorique de France, Paris: p. 165-175. (in French) ("The Magdalenian settlement in Auvergne")

Surmely, F. \& Pasty, J.-F. 2003, L'importation de silex en Auvergne durant la Préhistoire. In: Les matières premières lithiques en Préhistoire, actes de la table ronde internationale d'Aurillac. (Surmely F., Ed.), Association de préhistoire du Sud-Ouest, Cressensac: p. 327-342. (in French) ("The importation of flint in Auvergne during Prehistory")

Surmely, F., Boudon, P., Briot, D. \& Pin, C. 2008, La diffusion des silex crétacés dans le centre du Massif central durant la Préhistoire (Paléolithique, Mésolithique,

Néolithique). Contribution à l'étude de la circulation des matières premières sur de longues distances. Paléo, 20: 115-144. (in French) ("The distribution of Cretaceous flints in the center of the Massif Central during Prehistory (Palaeolithic, Mesolithic, Neolithic). Contribution to the study of the circulation of raw materials over long distances")

Talec, D. 2015, Des formations à silex à la visualisation des itinéraires: vers les cartes des gîtes potentiels. Mémoire d'ingénieur. École supérieure des géomètres et topographes du Mans, Le Mans, 55 p. (in French) ("From flint formations to the visualization of itineraries: Towards maps of potential raw material sources")

Thiry, M. 1981, Sédimentation continentale et altérations associées: Calcitisations, ferruginisations et silicifications. Les argiles plastiques du Sparnacien du Bassin de Paris. Ph.D. Thesis. Université de Strasbourg, Strasbourg, 173 p. (in French) ("Continental sedimentation and associated alterations: Calcitizations, ferruginizations and silicifications. The plastic clays of the Sparnacian of the Paris Basin.")

Thiry, M., Schmitt, J.M., Trauth, N., Cojean, R. \& Turland, M. 1983, Formations rouges « sidérolithiques » et silicifications sur la bordure nord du Massif Central. Revue de géologie dynamique et de géographie physique, 24(5): 381-395. (in French) ("Siderolithic red formations and silicification on the northern edge of the Massif Central.")

Thiry, M., Fernandes, P., Milnes, A. \& Raynal, J.P. 2014, Driving forces for the weathering and alteration of silica in the regolith: Implications for studies of prehistoric flint tools. Earth Science Review, 136: 141-154, doi:10.1016/j.earscirev.2014.05.008

Tomasso, A. 2014, Territoire, système de mobilité et système de production. La fin du Paléolithique supérieur dans l'arc liguro-provençal. Ph.D. Thesis. Université de Nice Sophia-Antipolis and Università di Pisa, Nice, 1069 p. (in French) ("Territory, mobility system and production system. The end of the Upper Palaeolithic in the liguroProvençal arc") 
Tuffery, C., Fernandes, P., Delvigne, V., Morala, A., Pinçon, G. \& Konik, S. 2017, Modélisation de données descriptives et spatiales sur les silex pour des projets de recherche collectifs en préhistoire. L'expérience en cours de plusieurs réseaux de lithothèque. In: Journée d'étude "Modélisation et élaboration conceptuelle de bases de données spatiales en archéologie et en histoire » du réseau ISA. Université de Pau et des pays de 1'Adour, laboratoire ITEM. 30/11/2017 and 01/12/2017. (in French) ("Modeling descriptive and spatial data on flint for collective research projects in prehistory. The ongoing experience of several lithothèque networks")

Tuffery, C., Fernandes, P., Delvigne, V. \& Morala, A. in press, Combinaison d'un SMA et d'un SIG pour aider à la prospection pétroarchéologique. Exploration d'une approche multi-agents dans la modélisation des parcours naturels du silex. Archéologies numériques (Digital Archaeology), 2(1): 17 p. (in French) ("Combination of an MAS and a GIS to assist in petro-archaeological prospecting. Exploration of a multi-agent approach in modelling natural flint paths") doi:10.21494/ISTE.OP.2018.0276

Turq, A. 2005, Réflexions méthodologiques sur les études de matières premières lithiques. Paléo, 17: 111-132. (in French) ("Methodological reflections on the studies of lithic raw materials")

Valensi, L. 1953, Microfossiles des silex du Jurassique moyen. Remarques pétrographiques. Société géologique de France, Paris, 100 p. (in French) ("Microfossils of Middle Jurassic flints. Petrographic remarks")

Valensi, L. 1954, Sur une meulière sphérolithique du calcaire lacustre du Berry. Bulletin de la Société géologique de France, 6 ème série, 3: 300-307. (in French) (“On a spherolitic stone of the lacustrine limestone of Berry")

Valensi, L. 1955a, Étude micropaléontologique des silex du Magdalénien de St-Amand (Cher). Bulletin de la Société Préhistorique française, 52(9): 584-596. (in French) ("Micropalaeontological study of Magdalenian flints from St-Amand (Cher)") doi:10.3406/bspf.1955.3263

Valensi, L. 1955b, Sur quelques microorganismes des silex crétacés du Magdalénien de SaintAmand (Cher). Bulletin de la Société Géologique de France, $6^{\text {ème }}$ série, 5: 35-40. (in French) ("On some microorganisms of the Cretaceous flints of the Magdalenian SaintAmand site (Cher)")

Valensi, L. 1957, Micropaléontologie des silex du Grand-Pressigny. Bulletin de la Société Géologique française, 6 ème série, 7: 1083-1090. (in French) ("Micropalaeontology of the Grand-Pressigny flints")

Vilas Boas, G. 1975, L'altération des accidents siliceux, silex et chailles dans les formations paléogènes du Bassin de Paris. Ph.D. Thesis, Université de Strasbourg, Strasbourg, 110 p. (in French) ("Alteration of flint and chert in the Palaeogene formations of the Paris Basin") 